\title{
$\frac{100}{\text { LAT RPESS }}$
}

\section{RESENTYMENTALNY RACJONALIZM W OCENIE POLSKICH CZASOPISM NAUKOWYCH: CHAOS, UPOLITYCZNIENIE I UTOWAROWIENIE}

\section{WPROWADZENIE}

Czasopisma naukowe, w polskim kontekście przede wszystkim w postaci tzw. wykazu czasopism naukowych i recenzowanych materiałów z konferencji międzynarodowych wraz z przypisaną liczbą punktów ${ }^{1}$, stanowią istotny komponent wiedzy naukowej. Ta ostatnia zaś, charakteryzująca się mocną zasada racjonalności ${ }^{2}$, by mogła być rozwijana poprzez krytyczną dyskusję, musi być komunikowana. Ponadto rezultaty badań naukowych upowszechniane w postaci artykułów, monografii, raportów czy referatów (po)konferencyjnych pełnią szersze role edukacyjne i transferu wiedzy między innymi w wymiarach społecznych, kulturowych, gospodarczych, technologicznych czy politycznych. Niniejszy artykuł, mając na celu charakterystykę kryteriów ewaluacji jedynie polskich czasopism naukowych, zawęża dodatkowo pole zainteresowania wyłacznie do nauk humanistycznych i społecznych. Zaproponowano pojęcie resentymentalnego racjonalizmu (RR), będące propozycją koncepcyjna, którego zamysłem jest przedstawienie wewnętrznych sprzeczności oraz absurdalności tzw. strategii ewaluacji polskich czasopism. Artykuł stanowi także przyczynek do szerszej dyskusji nad rolą periodyków naukowych we współczesnych, usieciowionych technologicznie, skomercjalizowanych oraz opartych na - w coraz większym stopniu - lapidarnych i nierzetelnych informacjach (fake news) ${ }^{3}$ społeczeństwach.

* Mariusz Baranowski, Uniwersytet im. Adama Mickiewicza w Poznaniu, mariusz.baranowski@amu.edu.pl, http://orcid.org/0000-0001-6755-9368, Redaktor naczelny czasopisma „Society Register”.

1 Ministerstwo Edukacji i Nauki (2021).

2 Ajdukiewicz (1965); Brzeziński (2000); Klebaniuk (2012); Such, Szcześniak (1997).

${ }^{3}$ Baranowski (2019a); Karas (2019); Molina, Sundar, Le, Lee (2021); Pedrini (2019); Sullivan (2019). 


\section{ZMIENIAĆ CZY NIE ZMIENIAĆ? RESENTYMENTALNY RACJONALIZM W DZIALANIU}

Rozpoczynając rozważania na temat statusu polskich czasopism naukowych z zakresu nauk społecznych i humanistycznych, warto uświadomić sobie, że materia sporu wobec tej problematyki jest niezwykle skomplikowana ze względu na szereg punktów widzenia i stanowisk zarówno technokratycznych (np. bibliometria vs. ocena ekspercka), jak i aksjonormatywnych (np. monografia vs. artykuł) czy czysto pragmatycznych (np. awanse, granty, ocena dyscyplin). Jedna kwestia zaś nie podlega dyskusji - standardy oceny czasopism naukowych musza być (a) opracowane, (b) precyzyjne i (c) znane społeczności naukowej. Mając na uwadze zwolenniczki i zwolenników „tego, co znane”, a także osoby, które opowiadają się za „tym, co (jeszcze) nieznane”, lub tych aktywnie angażujących się w krytyczne dysputy na temat kierunków zmian w ocenie czasopism naukowych, przytoczmy przestrogę Ericha Fromma z Rewolucji nadziei, w której twórca psychoanalizy humanistycznej stwierdził:

Podczas gdy bierne wyczekiwanie jest maska, pod którą kryje się desperacja i bezradność, istnieje też inna forma takiej rozpaczy, przejawiająca się poprzez ucieczkę w pustą frazeologię i awanturnictwo, lekceważenie wobec rzeczywistości i wymuszanie na niej tego, do czego zmusić nie można ${ }^{4}$.

Jeżeli „standardy” publikacyjne stanowią nie tylko bardzo ważny komponent kariery naukowej oraz oceny jednostek i/ lub dyscyplin, ale przede wszystkim kształtują dyskursy nad kluczowymi obszarami badań, to rozważając model oceny czasopism (a także monografii), należy porzucić owe maski czy formy rozpaczy. Takie stanowisko nie stoi w sprzeczności z krytyczną postawą wobec rzeczywistości ${ }^{5}$ czy propozycji jej zmiany ${ }^{6}$, ale wymaga wypracowania spójnej ramy teoretycznej, będącej podstawą analizy. Ta ostatnia natomiast implikuje konieczność sformułowania głównego celu (oraz celów szczegółowych), któremu służyć ma ewaluacja czasopism naukowych. Nie trzeba dodawać, że specyfika nauk humanistycznych i społecznych różni się od nauk formalnych bądź przyrodniczych ${ }^{7}$, co pociaga za sobą konieczność wypracowania swoistych kryteriów oceny. I w ten sposób natrafiamy na jawne i ukryte obszary konfliktowe, bezpośrednio związane z zagadnieniem władzy w polu nauki.

Biorąc pod uwagę wyłącznie polskich decydentów politycznych i ich naukowych popleczników, ocena czasopism - szczególnie w ostatnich latach wyłącznie „punktowo” i „spontanicznie” wpisuje się w pojęcie racjonalności ${ }^{8}$, rozumianej w tym kontekście jako systematyczne stosowanie kryteriów opartych na rozumie w celu osiagnięcia wcześniej zdefiniowanego i realistycznego

\footnotetext{
${ }^{4}$ Fromm (2017): 15.

${ }^{5}$ Baranowski (2019b).

${ }^{6}$ Karoński (2015).

${ }^{7}$ Chalmers (1997); Klementewicz (2020a); Kmita (1975): 163-219; Kozyr-Kowalski (2005);

${ }^{8}$ Schumpeter (1984).
} Whitehead (1929). 
celu. Jest to nie tylko konsekwencja braku ciagłości realizacji określonej polityki względem nauki i szkolnictwa wyższego, będącej konsekwencją różnic politycznych i wewnętrznych walk o wpływy. Chodzi raczej o brak jakiejkolwiek wizji nauki polskiej, nawet średniookresowej, której podporządkowana winna być ewaluacja czasopism i wydawnictw ${ }^{9}$. Ten brak to konsekwencja dominacji politycznego (czytaj: opartego na dogmatach partyjnego myślenia) sterowania nauka, która li tylko instrumentalnie posługuje się naukowcami w celu legitymizacji „swoich”, jakże licznych i zmiennych, reform. Brak wspólnego głosu społeczności naukowej, rozgrywanej za pomoca prymitywnego systemu kar i nagród, pogłębia ów chaos i irracjonalność następujących po sobie zmian. A to po tzw. elicie intelektualnej (badaczkach i badaczach) spodziewać powinniśmy się krytycznych i dalekowzrocznych realnych działań ${ }^{10}$, a nie cichego popierania szkodliwych rozwiązań przy - dla ostrości wywodu dodam - „nic nieznaczacych” oświadczeniach, uchwałach, petycjach i komunikatach „prawie-krytyki” i „prawie-oburzenia”"11.

W wyniku tych szkodliwych i nieskoordynowanych działań politycznych i braku realnej reakcji środowiska naukowego wypracowany został w naszym kraju specyficzny rodzaj „racjonalności” w ocenie czasopism naukowych. Proponuję określić ją jako „resentymentalną racjonalność” (RR), gdyż przywodzi na myśl znaczenie nadane temu terminowi przez niemieckich humanistów. Otóż według Maxa Schelera resentyment to

[...] duchowe samozatrucie, które ma ściśle określone przyczyny i skutki. Jest to trwałe nastawienie psychiczne, które rodzi się, kiedy określone odruchy uczuciowe i namiętności - same przez się normalne i zasadniczo wchodzące w skład ludzkiej natury - ulegają systematycznie stłumieniu i nie zostają rozładowane, pociagając za sobą pewne trwałe skłonności do określonego rodzaju złudzeń co do wartości i odpowiadających im sądów wartościujących. Odruchami uczuciowymi i namiętnościami, które przede wszystkim wchodza tu w grę, sa: mściwe uczucie i odruch zemsty, nienawiść, złośliwość, zazdrość, zawiść, szyderstwo ${ }^{12}$.

Analogia pomiędzy powyższym cytatem a kolejnymi „kierunkami” reform (szczególnie konkurencyjnych ugrupowań politycznych następujących po sobie i sprawujących władzę) czy stanowiskami gremiów lub środowisk naukowych (które raz były dowartościowane przez urzędnika ministerialnego, a innym skarcone niczym niegrzeczne dziecko) jest aż nadto oczywista. Odczuwane poczucie bezsilności, upokorzenia i zazdrości w jednym rozdaniu ewaluacyjnym, przybiera na determinacji w poparciu „nowej i słusznej” listy czasopism punktowanych. „Obdarowani” już nawet nie udaja zażenowania

9 Karoński (2015).

10 Nature (2019): 153.

11 Dla głębszego zrozumienia tego zjawiska przytoczmy znaczenie pojęcia „nieczysta krytyka”, wprowadzonego przez Evę Illouze (2010: 137-138), które oznacza taki „rodzaj krytyki, która usiłuje balansować na cienkiej linie pomiędzy tymi praktykami, które odpowiadają pragnieniom i potrzebom samych ludzi, bez względu na to, jak mogą się nam wydawać niesmaczne, a tymi praktykami, które utrudniają im osiąanie celów”.

12 Scheler (1997): 33-34. 
brakiem racjonalności w podejmowaniu bezprawnych decyzji „samowładnych obdarowujących”, ponieważ „duchowe zatrucie” zainfekowało kluczowe organy i zbiera swoje żniwo ${ }^{13}$.

\section{Schemat 1}

Racjonalne działanie versus resentymentalny racjonalizm
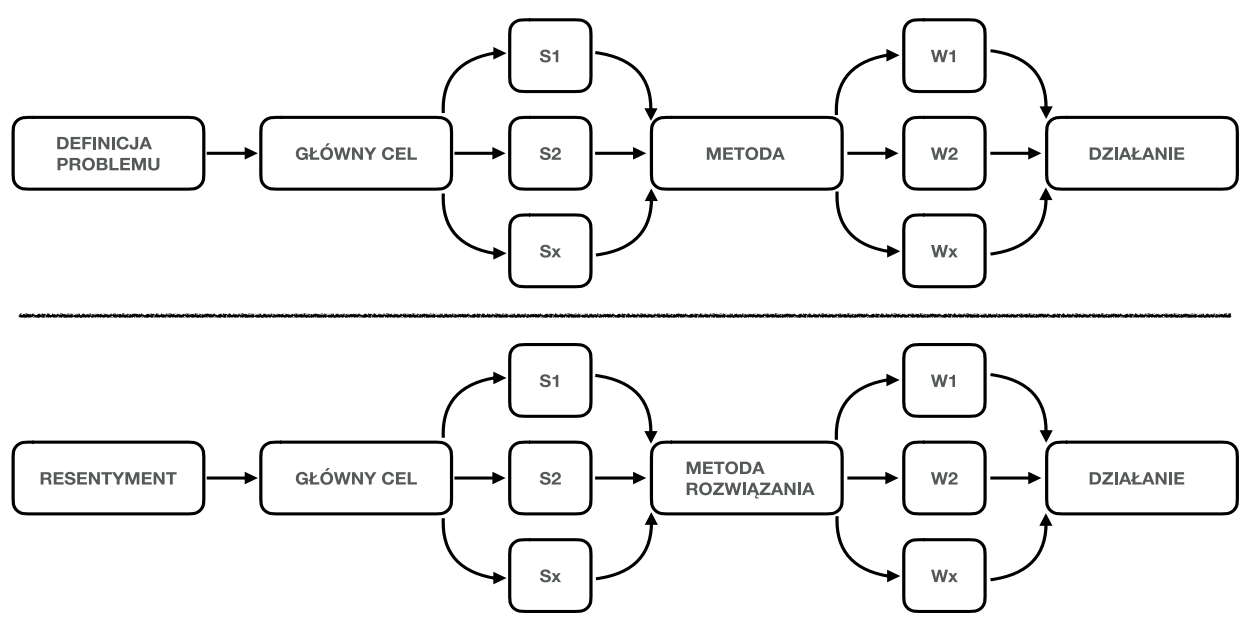

Źródło: opracowanie własne.

Ta swoista trajektoria (lub lepiej - karuzela) w zmianach warunków oceny czasopism służy wszystkiemu tylko nie przejrzystości i poprawie stanu polskiej nauki w Europie i w świecie, ze stabilnością pracy naukowej i funkcjonowania uczelni włącznie. Schemat 1 pokazuje zasadnicze różnice w działaniu racjonalnym i resentymentalnym. Podczas gdy ten pierwszy opiera się na wyartykułowaniu problemu do rozwiązania, postawieniu głównego celu działania oraz celów szczegółowych (S1, S2, Sx), a także wybraniu optymalnej metody (mogącej przybierać różne warianty rozwiązania problemu - W1, W2, Wx), to logika drugiego jest zasadniczo odmienna. Przede wszystkim wypływa z resentymentu, który impregnuje zarówno cele działania, jak i metodę (często zresztą formułowaną ad hoc). Formalnie rzecz ujmujac, te dwa sposoby działania posiadają podobną strukturę, lecz w rzeczywistości ich „logiki” są niewspółmierne. Resentymentalny racjonalizm wpisuje się w argumentację Bertranda Russella, który stwierdził, że „źródłem zła, które ludzie sobie i innym wyrządzaja, są złe namiętności, a nie idee czy przekonania. Te ostatnie stanowią najczęściej tylko przykrywkę dla złych namiętności”"14. Nie

13 „Przeżytki i nawroty rytualizmu objawiają się z całą siłą i najbardziej spontanicznie właśnie w tych uczelniach, których działalność polega przede wszystkim na kształceniu przedstawicieli klasy próżniaczej i duchowieństwa” (Veblen 2008: 311).

14 Russell (1997): 171. 
zapominajmy jednak, że owe namiętności mogą skutkować - użyjmy określenia niedawno zmarłego antropologa gospodarki - „zrutynizowaniem stosowania przemocy"15.

\section{DLACZEGO W OGÓLE MAMY OCENIAĆ CZASOPISMA?}

Trudno wyobrazić sobie sytuację, w której społeczność naukowczyń i naukowców nie jest w stanie wyartykułować głównego celu funkcjonowania i różnicowania czasopism naukowych oraz wydawnictw. Fakt, że różne środowiska naukowe mogą prezentować przeciwstawne, a nawet otwarcie antagonistyczne punkty widzenia, nie powinno być zaskoczeniem. Wszak odmiennych dyscyplin, a nawet poszczególnych szkół w ich ramach, stosuja różnorakie podejścia i metody badawcze, odwołujące się do niewspółmiernych orientacji teoretyczno-metodologicznych. Zdarzają się także piewcy rezygnacji z oceny periodyków, jednakże takie podejście - oprócz określonych zalet - nie rozwiąuje istotnego problemu „byle jakich”, nierzetelnych, pseudonaukowych i drapieżnych (ang. predatory) czasopism ${ }^{16}$. Słowem, brak ewaluacji explicite tak czy inaczej wymusza stosowanie praktyk oceny implicite. Badaczki i badacze muszą ostatecznie zdecydować, w których tytułach opublikować swoje wyniki, co oznacza, że eo ipso zadadzą sobie trud ich porównywania. A w wyniku tych (początkowo spontanicznych) działań i tak pojawią się najpierw intuicyjne, a z czasem coraz bardziej usystematyzowane rejestry czasopism. Nie wspominając o konieczności oceny poszczególnych dyscyplin i/ lub jednostek naukowych, z systemem grantów i stypendiów na czele, które wymagają określonych i porównywalnych wytycznych na temat wytworów społeczności badaczek i badaczy.

Powyższa linia argumentacji, szczególnie w polskich warunkach permanentnej, chaotycznej i upolitycznionej reformy szkolnictwa wyższego, nie może abstrahować od przesłanek zaprezentowanych przez na przykład Przemysława Czaplińskiego, który zauważył, że „społeczeństwo wiedzy miało powstać niejako "samo« - w wyniku żywiołowego procesu studiowania. Elitarność polskich uczelni również ma powstać "sama" - w wyniku dostosowania polskiej parametryzacji do światowych list rankingowych"17.

$\mathrm{Z}$ jednej strony bezmyślne reprodukowanie modeli biznesowych wielkich kapitalistycznych korporacji wydawniczych w rodzaju Elsevier, Sage, Routledge, Wiley, Springer ${ }^{18}$ czy Oxford University Press posiada wiele słabości, szczególnie z perspektywy kraju, którego wydatki na badania i rozwój nie pozostawiają złudzeń. Jak zauważyła bowiem Katarzyna Ziętek-Kwaśniewska: „biorąc pod uwagę kształtowanie się wskaźnika BERD/PKB w 2018 r., podob-

\footnotetext{
15 Graeber (2016): 231.

${ }^{16}$ W kontekście krytyki tzw. oceny eksperckiej wydziałów prawa w Niderlandach, zob. Słomczyński (2021).

17 Czapliński (2019): 5.

18 Baranowski (2020): 394 i 398.
} 
nie jak w przypadku relacji GERD/PKB, Polska zajęła odległa, bo 15. pozycję wśród państw UE, uzyskując wynik prawie trzykrotnie niższy niż zajmujacca pierwszą lokatę Szwecja" ${ }^{19}$.

Z drugiej natomiast - przeprowadzana przez lata elitarystyczna reforma polskich szkół wyższych jest antyludowa ${ }^{20}$, gdyż faworyzuje uprzywilejowane części społeczeństwa. O ile ten drugi argument nie został sformułowany bezpośrednio w nawiązaniu do ewaluacji czasopism naukowych, to dotyczy także tego obszaru, ponieważ „problem polega na tym, że beneficjentem elitaryzmu wcale nie będzie społeczeństwo w całości, lecz - jak zauważa Czapliński - klasa średnia (zwłaszcza jej górna frakcja) i klasa wyższa" ${ }^{21}$. Na poziomie analizy osób idących na studia chodzi o osoby z relatywnie zamożnych środowisk. To ich przedstawiciele konstytuuja (i proces ten będzie się pogłębiał) społeczność pracowniczek i pracowników uczelni wyższych, co w świetle wspomnianej elitaryzacji wzmocni jeszcze bardziej status największych uczelni w czołowych polskich miastach. Ten istny drenaż mózgów, tj. przepływ najlepszych naukowczyń i naukowców z mniejszych ośrodków do największych i najlepszych, legitymizowany jest rankingami uczelni wyższych (i ich możliwościami finansowymi oraz symbolicznymi) wyznaczanymi na podstawie „wyceny” czasopism naukowych i wydawnictw. Inna sprawa dotyczy tego, czy rzeczywiście potrzebujemy w Polsce ponad 400 uczelni.

Ta linia argumentacji prowadzi do ważnego problemu - szczególnie dyskutowanego w kontekście tzw. reformy Gowina - przyszłości szkół wyższych $\mathrm{w}$ mniejszych miejscowościach ${ }^{22}$. Uczelnie te w warunkach polskich sytuowane są w dołach rankingów, co wedle założeń rzeczonej reformy i przyjętego przez nią algorytmu podziału środków budżetowych przekłada się na mniej atrakcyjny sposób finansowania ${ }^{23}$. Rodzi to pytania o przyszłość szkół wyższych poza największymi miastami i dostęp do kształcenia na tym poziomie dla osób spoza głównych ośrodków i niedysponujących środkami finansowymi, by do nich się przeprowadzić na czas studiów. A warto pamiętać w tym miejscu o raporcie Programu Kariera Polskiej Rady Biznesu „Student w pracy 2019”, że w naszym kraju nawet $82 \%$ osób studiujących pracuje (z czego zdecydowana większość to studenci studiów dziennych) ${ }^{24}$. Patrząc na wykres 1 , na którym zestawiono wielkość województw z ilością studentów ogółem, widać wyraźnie, że im liczebniejsze województwo, tym - co nie jest żadnym zaskoczeniem - więcej studiujących. Dominacja mazowieckiego i szczególnie Warszawy, a także małopolskiego, wielkopolskiego, dolnoślasskiego i śląskiego mówi też dużo o lokalnych rynkach pracy, które nie tylko są w stanie zachęcić młodych do wyboru dużych regionalnych ośrodków, lecz także zaproponować im zatrudnie-

19 Ziętek-Kwaśniewska (2020): 21.

${ }^{20}$ Czapliński (2019).

21 Czapliński (2019): 5.

${ }^{22}$ Krzemiński (2019); Nowakowska (2018).

${ }^{23}$ Klauziński (2016).

${ }^{24}$ Student w pracy 2019. Raport badawczy. Polska Rada Biznesu. Program Kariera. SW Research. <https:/prb.pl/wp-content/uploads/2019/04/Raport-Student-w-Pracy-2019-wyniki-.pdf>. 
nie $^{25}$. A to przyczynia się do ukształtowania studentyfikacji, rozumianej przeze mnie jako specyficzna odmiana dualnego rynku pracy, opartego na sile roboczej osób studiujących (co wywiera określony wpływ na warunki zatrudnienia niestudentów).

\section{Wykres 1}

Studenci ogółem według wielkości województwa

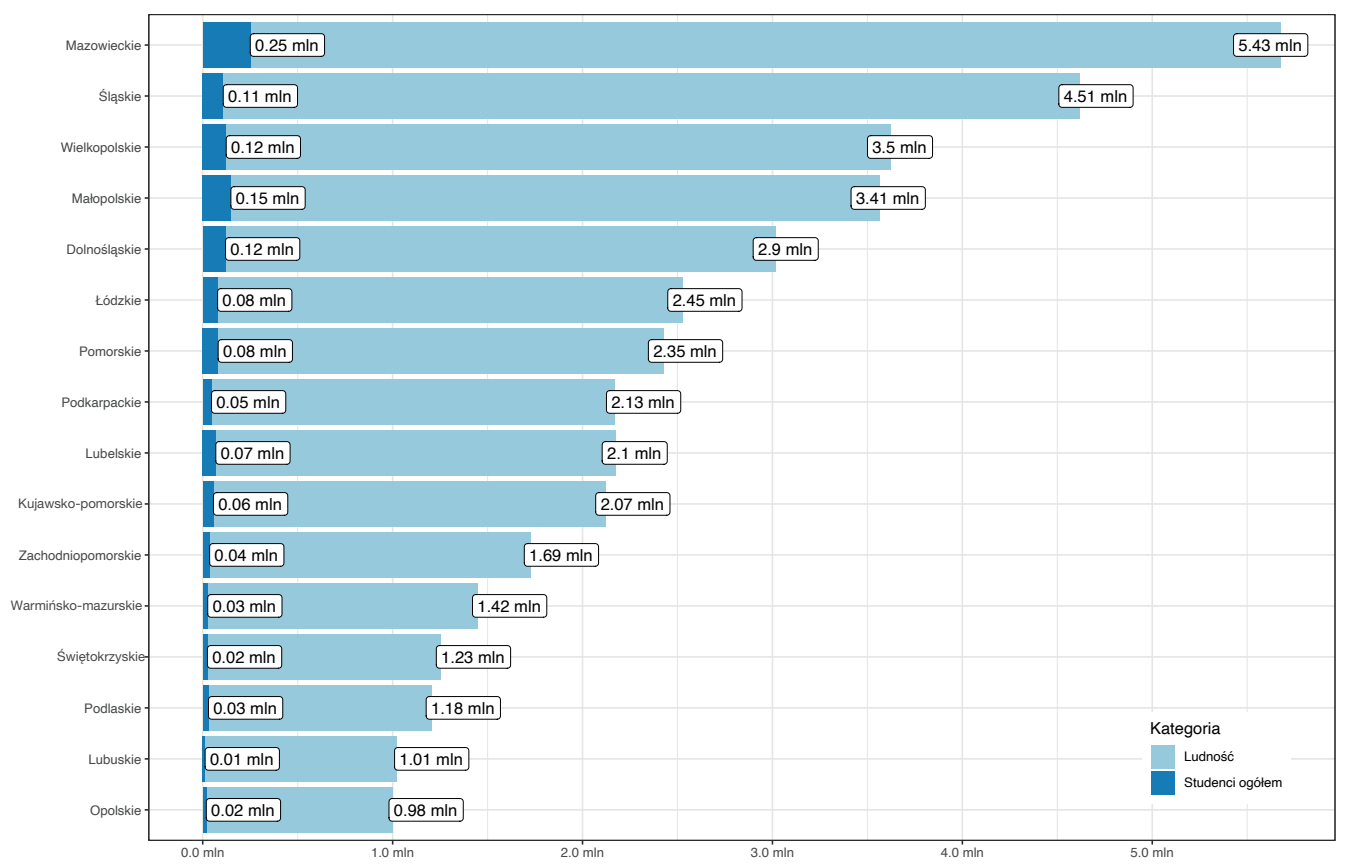

Źródło: opracowanie własne na podstawie GUS (Szkolnictwo wyższe w roku akademickim 2018/2019) oraz GUS (Ludność. Stan i struktura ludności oraz ruch naturalny w przekroju terytorialnym, stan w dniu 30.06.2020).

Ewaluacja czasopism i wydawnictw tymczasem przekłada się na oceny badaczek i badaczy, ich zdolności pozyskiwania grantów i stypendiów, a także ich dyscyplin, a zatem i instytucji (uniwersytetów, politechnik, akademii itp.). To z kolei kształtuje zarówno ogólnopolską mapę uczelni oraz ich potencjału ${ }^{26}$, jak i wpływa na podziały klasowe i szanse życiowe całych grup społecznych (Andrzej W. Nowak pisał ponad dekadę temu o „niezauważalnej roli uniwersytetu w procesie akceleracji rozwarstwienia społecznego" ${ }^{27}$ ).

25 Rozsądną propozycję zaprezentował Michał Karoński (2015: 28), podkreślając, że „musimy zbudować system elitarnych uczelni, uzupełniany rozsądnie skonstruowanym systemem kształcenia masowego".

${ }^{26}$ Akademickość polskich miast (2019).

27 Nowak (2010): 211. 
Ocena czasopism naukowych, będąca podstawą - bardzo istotnej zresztą ewaluacji instytucji naukowych, wpływa wielopoziomowo również na zjawiska co najwyżej uwarunkowane i doniosłe naukowo, acz o ważnej roli z perspektywy skomplikowanego społeczeństwa jako całości. Warto mieć to na uwadze, przyglądając się praktykom ewaluacji periodyków w Polsce.

\section{CHAOS}

Reformy polskiej nauki i szkolnictwa wyższego przybrały na dynamice i zyskały rozgłos od czasów Barbary Kudryckiej na czele resortu (2007-2013), wtedy już mówiono o szczególnym dofinansowaniu „flagowych”28, czyli najlepszych uczelni. Dwuletni okres kierowania MNiSW Leny Kotlarskiej-Bobińskiej (od 2013 do 2015) to kontynuacja reform poprzedniczki. Prawdziwa „rewolucja” nastała za czasów Jarosława Gowina (2015-2020) ${ }^{29}$, z jego tzw. Konstytucją dla Nauki - ustawą 2.030, i Przemysława Czarnka (który zastapił po 6 miesiącach Wojciecha Murdzka), z ,jego autorską" listą czasopism punktowanych.

Gwoli ścisłości pamiętać należy, że zmiany w obrębie polityki naukowej państwa, które obejmują ocenę czasopism, następowały dynamicznie po 1989 r. Przypomnę tylko, że głównym podmiotem organizującym ten obszar działalności społeczeństwa w latach 1991-2004 był Komitet Badań Naukowych (KBN), którego kompetencje na mocy ustawy z 8 października 2004 r. przejał minister odpowiedzialny za naukę. Listy czasopism punktowanych były publikowane regularnie od $2004 \mathrm{r} .{ }^{31}$, następnie były uaktualniane. Budziły - z dzisiejszej perspektywy powiedzielibyśmy umiarkowane - dyskusje i kontrowersje w środowisku naukowym, ponieważ na ich podstawie przeprowadzano oceny jednostek naukowych i poszczególnych badaczek i badaczy.

Prawdziwy chaos nastapił pod koniec lipca 2019 r. wraz z opublikowaniem komunikatu Ministra Nauki i Szkolnictwa Wyższego z 31 lipca 2019 r. w sprawie wykazu czasopism naukowych i recenzowanych materiałów z konferencji międzynarodowych wraz z przypisaną liczbą punktów ${ }^{32}$. Przede wszystkim zastosowane kryteria oceny czasopism nie były znane redaktorkom i redaktorom

28 Pezda, Uhlig (2008).

29 Leszczyński (2020); Odrowąż-Coates (2020); Śliwerski (2019).

30 Chodzi o ustawę z 20 lipca 2018 r. - Prawo o szkolnictwie wyższym i nauce.

31 Z wyjątkiem 2011 i 2017 r. Zob. MNiSW, Informacja dotycząca nieprzeprowadzenia oceny czasopism naukowych w 2017, <https://www.gov.pl/web/edukacja-i-nauka/informacja-dotyczacanieprzeprowadzenia-oceny-czasopism-naukowych-w-2017>.

32 Komunikat Ministra Nauki i Szkolnictwa Wyższego z 31 lipca 2019 r. w sprawie wykazu czasopism naukowych i recenzowanych materiałów z konferencji międzynarodowych wraz z przypisaną liczbą punktów, <http://www.bip.nauka.gov.pl/akty-prawne-mnisw/komunikatministra-nauki-i-szkolnictwa-wyzszego-z-dnia-31-lipca-2019-r-w-sprawie-wykazu-czasopismnaukowych-i-recenzowanych-materialow-z-konferencji-miedzynarodowych-wraz-z-przypisanaliczba-punktow.html>. 
wcześniej, a zatem nie było możliwości wdrożenia „oczekiwanych standardów”. Okazało się post factum, iż sam proces ewaluacji przeprowadzili naukowcy-specjaliści podzieleni na 44 zespoły doradcze. Jednakże i tu nie zabrakło ułańskiej fantazji, ponieważ - jak zauważył jeden ze specjalistów, Dariusz Jemielniak - doszło do jawnych wypaczeń wyników pracy owych zespołów:

[...] już widzę, że z tego, co proponowaliśmy, część uległa istotnym przetasowaniom - zatem oceny eksperckie zostały w sposób dosyć niejawny pozmieniane, mam nadzieję, że zostanie powiedziane przez kogo i wedle jakiej logiki nadrzędnej ${ }^{33}$.

Po wtóre, lista działała wstecz, co oznacza, że badaczki i badacze mieli być oceniani na podstawie kryteriów, których nie znali. To nie tylko kuriozum prawne (dokładnie: bezprawne), ale także brak fundamentalnego poszanowania pracy całej wspólnoty uczonych, która poddana jest - patrz następny punkt - upolitycznionym eksperymentom.

W końcu ciąłe zmiany nietransparentnych kryteriów raz oparte mają być na określonych bazach i ich wskaźnikach (Web of Science, Scopus lub ERIH+), innym razem także/ głównie na ocenie eksperckiej. Ta ostatnia w przypad$\mathrm{ku}$ czasopism nieujętych w międzynarodowych bazach wymagała udziału o czym redakcje dowiedziały się bardzo późno - w konkursie w ramach programu „Wsparcie dla czasopism naukowych”, przeprowadzonym w październiku 2018 r.

Według deklaracji Jarosława Gowina lista czasopism i wydawnictw punktowanych, oprócz pragmatycznego celu ewaluacji jakości działalności naukowej, którą początkowo zaplanowano na rok 2021, miała dokonać istotnej korekty w sposobie „wyceny” jakości polskich i zagranicznych periodyków naukowych. Natomiast cała reforma nauki i szkolnictwa wyższego (z idea uczelni badawczych na czele) sygnowana jego nazwiskiem doprowadzić miała do podniesienia pozycji polskich uczelni w międzynarodowych rankingach ${ }^{34}$. Jakość publikacji stanowi istotny komponent owych rankingów, lecz wyselekcjonowane bazy referencyjne i rankingi uczelni w ogóle obarczone są szeregiem jawnych wypaczeń ${ }^{35}$.

Jeśli ktoś uważa, że to pełen obraz chaosu w ocenie polskich czasopism (określony w kontekście całokształtu zmian przez Tadeusza Klementewicza „deformą” Gowina ${ }^{36}$ lub w innym miejscu „reformą-deformą polskiej humanistyki” ${ }^{37}$ ), to warto przyjrzeć się poczynaniom obecnego ministra, Przemysława Czarnka ${ }^{38}$.

${ }^{33}$ Leszczyński (2019).

34 Tomala (2019).

${ }^{35}$ Chawla (2021); Espeland, Sauder (2016); Gadd (2020); Grudniewicz, Moher, Cobey et al. (2019); Lydgate (2018); McKenna (2020).

36 Klementewicz (2020b): 36-38.

37 Klementewicz (2019): 28.

38 Leszczyński (2021a), (2021b); Sewastianowicz (2021); Szczepański (2021). 


\section{UPOLITYCZNIENIE}

Zanim przyjrzymy się najnowszej liście czasopism punktowanych, wpisującej się w tytuł tej części artykułu, słów kilka o upolitycznieniu pola nauki ${ }^{39}$. Obszar szeroko rozumianej pracy naukowej, zorganizowanej na przykład w publicznych i prywatnych uczelniach i jednostkach badawczo-rozwojowych, wiąże się bezpośrednio ze znacznymi wydatkami budżetowymi państwa i podmiotów prywatnych (finanse) oraz władzą (np. polityka, kultura), a zatem ma charakter konfliktowy. Najistotniejszą kwestia jest rola, jaką odgrywa ministerstwo w ewaluacji dyscyplin i samych naukowczyń i naukowców, szczególnie mając na względzie „profil” ideologiczny urzędników państwowych z nadania partyjnego ${ }^{40}$. Żeby sprawa była jasna, nie chodzi o krytykę jednej orientacji ideologicznej czy afirmację drugiej, tylko o mechanizm odpolitycznienia pola nauki, szczególnie w kontekście ocen jednostek i samych badaczy. Ewaluacja dyscyplin czy pracowników musi być dokonywana przez ciała powoływane w sposób demokratyczny i spośród społeczności badaczek i badaczy, które - jak we Włoszech ${ }^{41}$ - można zaskarżyć do sądu. Inaczej będzie dochodziło do sytuacji w rodzaju tej z Komisja Ewaluacji Nauki, której wytyczne minister Czarnek pominą ${ }^{42}$. Według Grzegorza Wierczyńskiego, przewodniczącego Zespołu do spraw Punktacji Czasopism Naukowych Komitetu Nauk Prawnych Polskiej Akademii Nauk, to, że do „listy opracowanej przez KEN dopisano 73 czasopisma, które nie były rekomendowane przez KEN, a 237 czasopismom podniesiono punktację, często na poziomie, który w ogóle nie jest dopuszczalny w ich przypadku” ${ }^{43}$, „to jest oczywiste złamanie prawa" ${ }^{44}$. Nie zmienia to faktu, że KEN swoim istnieniem legitymizuje obecny stan chaosu i upolitycznienia, nie tylko przez zaniechanie realnych działań naprawczych (oświadczenie z 11 lutego to wyłącznie pozorowany i w rzeczywistości nic niezmieniający zabieg), ale przede wszystkim przez brak opracowania i publicznego ogłoszenia tak banalnych i technicznych elementów, jak chociażby terminarz i warunki aplikacji (i) „nowych” periodyków do uaktualnianych listy, (ii) zmiany punktacji czasopism ze względu na ich - pominięte w ewaluacji - dostanie się do baz referencyjnych czy (iii) możliwości poszerzenie dyscyplin dla rozwijających się przecież tytułów.

Jakby mało było tego chaosu, do tej niezgodnej z nomen omen z własnym rozporządzeniem (sic!) listy czasopism z 10 lutego, minister Czarnek już po

${ }^{39}$ Zob. Bourdieu, Wacquant (2001).

40 „Groźba wyraźnego przesunięcia polityki w kierunku nacjonalistycznej albo konfesyjnej demagogicznej radykalnej prawicy jest prawdopodobnie największa w dawniejszych krajach komunistycznych oraz Azji Południowej i Wschodniej, najmniejsza zaś w Ameryce Łacińskiej” (Hobsbawm 2013: 448).

${ }^{41}$ Słomczyński (2021).

${ }_{42}$ Zob. Oświadczenie Komisji Ewaluacji Nauki z 11 lutego br. w sprawie znowelizowanego wykazu czasopism naukowych i recenzowanych materiałów z konferencji międzynarodowych, $<$ https://forumakademickie.pl/sprawy-nauki/oswiadczenie-komisji-ewaluacji-nauki/>.

${ }^{43}$ Sobczak (2021).

${ }^{44}$ Sobczak (2021). 
dziewięciu dniach raz jeszcze ją niezgodnie z prawem zmodyfikował. W wyniku manipulacji wykazem czasopism punktowanych dowartościowane zostały przede wszystkim periodyki „związane np. z teologia, filozofią katolicką czy prawem kanonicznym" ${ }^{45}$.

Przyglądając się upolitycznieniu oceny czasopism humanistycznych, społecznych i teologicznych, łamiącej prawo i dobre zwyczaje, nie możemy stracić z pola widzenia bardziej zasadniczych cech zaadaptowanego w Polsce model, w którym ,[...] narzucony przymusem administracyjnym reżim publikacyjny wymusza i miejsce, i - wbrew pozorom - tematykę poszukiwań badawczych (»co się sprzeda, a co nie - w grantach i w publikacjach«). Dlatego mamy tu do czynienia z systemowym gwałtem na autonomii procesów poznawczych, wolności nauki i służbie jakości społeczeństwa obywatelskiego"46.

W tym kontekście właśnie, rozważając kwestię upolitycznienia nauki we współczesnej Polsce, warto przyjrzeć się charakterystyce sytuacji w Rosji, która choć dokonana wiele dekad temu przez Bertranda Russella, to zdradza nader aktualne konotacje. Otóż, jak zauważył angielski filozof i matematyk, „W sferze kultury warunkiem postępu jest różnorodność. Instytucje cieszące się pewną niezależnością od państwa, jak uniwersytety i towarzystwa naukowe, maja pod tym względem nieocenioną wartość. Ubolewania godna jest sytuacja - jak w [...] Rosji - gdy uczeni muszą się podpisywać pod obskurancka bzdurą na rozkaz nie mających pojęcia o nauce polityków, którzy poprzez naciski ekonomiczne i z pomocą policji mogą narzucać swoje śmieszne pomysły. Tego rodzaju żałosnemu widowisku da się zapobiec tylko wtedy, gdy działania polityków zostaną ograniczone do dziedzin, w których są oni kompetentni”"

Ten naszkicowany powyżej kierunek zmian jest nieunikniony, jeżeli mamy na uwadze dobro polskiej nauki i szkolnictwa wyższego, które oprócz natychmiastowego odpolitycznienia potrzebuja również radykalnej transformacji feudalnych stosunków w akademii. Powrót do stanu sprzed reformy Gowina nie jest żadnym rozwiązaniem.

\section{UTOWAROWIENIE}

Wytwory pracy naukowców stają się towarami, podobnie jak towarami sa punkty za publikacje naukowe. Towarami, to znaczy dobrami lub - stosujacc myślenie socjologiczne - stosunkami społecznymi, które posiadają wartość wymienna ${ }^{48}$. Nawet - zdawałoby się tak mało praktyczne - wyniki badań społecznych „sa przydatne korporacjom dla efektywności przemysłu kulturowego, sterowania zachowaniami konsumenckimi i ich odmiana: wyborczymi, urabiania postaw wobec Systemu"49. Punkty za publikacje podobnie: oprócz wartości

\footnotetext{
45 Leszczyński (2021b).

46 Klementewicz (2019): 21.

${ }_{47}$ Russell (1995): 112-113.

48 Ziółkowski, Drozdowski, Baranowski (2020): 56.

49 Klementewicz (2019): 28.
} 
użytkowej posiadają wartość wymienną o bardzo skwantyfikowanym charakterze, podobnym w swej naturze do pieniędzy, a na pewno przekładające się na te ostatnie.

Gwoli ścisłości, polski rynek czasopism naukowych, bardzo zreszta zróżnicowany wewnętrznie, choć utowarowiony (podobnie jak szkolnictwo wyższe ${ }^{50}$ ), to jeszcze nie jest skomercjalizowany na podobieństwo głównie zachodnich odpowiedników ${ }^{51}$. Największe wydawnictwa światowe doprowadziły do utowarowienia, urynkowienia i komercjalizacji informacji naukowej w takim zakresie, że „w coraz większym stopniu nawet bibliotek, nie mówiąc już o odbiorcach indywidualnych, nie stać na zakup książek naukowych, prenumeratę czasopism, które powinny się znaleźć w ich zasobach" ${ }^{2}$.

Szczególnie w kontekście czasopism dominuje w Polsce model otwartego dostępu do artykułów na zasadach licencji Creative Commons, choć poszczególne tytuły realizuja odmienne praktyki. Nie oznacza to wcale, że procesy komodyfikacji wytworów nauki nie postępują. Wręcz przeciwnie. Nie wchodząc w detale utowarowienia szkolnictwa wyższego w ogóle, uwaga zostanie skupiona na praktykach publikacyjnych. Praktyki te bowiem w postaci systemu punktowego, określanego potocznie jako „punktoza”s3, nie służą wyłącznie celom parametryzacji. Odgrywają istotną „rolę statusowa” oraz posiadają swoista wartość wymienna, transferowalną (bezpośrednio i pośrednio) między innymi na: awanse, nagrody, bezpieczeństwo zatrudnienia, granty (,grantoza”) i stypendia zagraniczne (,stypendoza”). Ponieważ punkty funkcjonują jako towary, więc przekładają się na szersze więzi i relacje w uczelniach wyższych i jednostkach badawczo-rozwojowych. Maja swoje odzwierciedlenie zarówno w strategiach prowadzenia badań, jak i poczucia sensu pracy naukowo-badawczej.

W atmosferze braku jasności kryteriów oceny jednostkowej i instytucjonalnej, które oparte są na tzw. punktach ministerialnych, dochodzi do swoistej „tresury pedagogicznej”"54, której naocznym efektem są dyskusje i komunikaty na temat ilości zdobytych punktów. Nie ma już miejsca na merytoryczne dyskusje o ważnych problemach społecznych i metodach ich badania, na spory i polemiki, ponieważ pogoń za punktami, na wzór ekonomicznej pogoni za rentą (ang. rent-seeking) ${ }^{55}$, zdominowała niepewne i kapryśne egzystencje badaczek i badaczy uzależnionych od ciagłego procesu oceny ich aktywności. Fetyszyzacja punktów, które stały się cennymi towarami w relacjach wymiany naukowo-biznesowej, doprowadziła do sytuacji - określę to bardzo dosadnie wyjałowienia poznawczych debat i eksploracji. Doświadczamy braku dyskusji na temat jakości publikowanych raportów, rzetelności i adekwatności stosowanych metod czy po prostu fake news’ów, rozprzestrzeniających się także $\mathrm{w}$ czasopismach naukowych ${ }^{56}$.

\footnotetext{
50 Pokusińska (2020).

51 Baranowski (2020).

52 Tittenbrun (2014): 171.

${ }^{53}$ Kulikowski, Antipow (2020).

54 Sloterdijk (2011): 79.

55 Welsh (2020).

$56 \operatorname{Lim}(2020)$.
} 
Kilka lat temu Andrzej Walicki, krytykując kierunek reform Barbary Kudryckiej, stwierdził:

W USA, traktowanych przez naszych reformatorów nauki jako wzór do naśladowania, nie istnieje zatem i nie może istnieć system 'parametryzacji', czyli uzależnienia karier naukowych od punktacji wymyślonej na użytek biurokratów, a w zastosowaniu do humanistów nie ma też żadnych nacisków na zdobywanie grantów ${ }^{57}$.

Funkcjonujący w naszym kraju utowarowiony system nauki oparty na punktach, dowolnie przyznawanych, szczególnie czasopismom za zakresu humanistyki i nauk społecznych, reprodukuje w coraz szerszym zakresie mechanizm rywalizacji rynkowej ${ }^{58}$. W ten sposób nie tylko ogranicza wolność badań naukowych, lecz także tworzy mechanizm permanentnej niepewności ${ }^{59}$ oraz ułudę „doganiania” czołówki światowej. Jeśli chodzi o tę ostatnią kwestię, to skwitujmy ja krótko za artykułem Mieczysława Jałochowskiego, o wymownym tytule Uczelnie - plantacja cherlawych paprotek, że budżet Uniwersytetu Stanforda jest wyższy od całych wydatków na szkolnictwo wyższe w Polsce ${ }^{60}$.

\section{PODSUMOWANIE}

Przedstawiona tu - skrótowo siłą rzeczy - quasi-analiza praktyk oceniania polskich czasopism naukowych w ostatnich latach skupiona została na wyartykułowaniu lokalnej specyfiki reform, które wpisują się w koncepcyjną propozycję resentymentalnego racjonalizmu. Stanowisko to, intencjonalnie oparte na contradictio in adiecto, miało na celu uwypuklić dezorganizację i brak koherencji w licznych ewaluacjach, skutkujących tym, że „politycy i współpracująca z nimi część środowiska dokonali wspólnie wiele wysiłków, żeby dużo zmieniając, nic nie zmienić" ${ }^{61}$. Chodzi przy tym o istotny komponent naukowego krajobrazu, przekładający się na wymierne rezultaty finansowania badań naukowych, uczelni i jednostek badawczo-rozwojowych oraz zatrudniania/ zwalniania pracowników. O jakości publikowanych wyników badawczych i ich społecznej użyteczności nie wspominając. Opisane pokrótce działania przywodzą na myśl i prowadzą do - użyjmy określenia Schelera - „znamiennego zafałszowania faktycznego obrazu świata”"62, który charakterystyczny jest dla osób powodowanych tymi złymi namiętnościami lub

57 Walicki (2013).

58 Według Alaina Touraine’a (2010: 36): „[...] wszelkie stosunki społeczne, bez względu na różnice między nimi - przedmiotem socjologii nie jest bowiem rzecz, lecz pewien zabieg: ujawnianie stosunków kryjących się za sytuacjami. Nie ważne, czy chodzi o stosunki klasowe, relacje wpływu, zróżnicowanie funkcjonalne, relacje hierarchiczne, czy relacje na polu walki. Każda duża kategoria stosunków społecznych tworzy odrębną dziedzinę analizy socjologicznej”.

59 Baranowski (2017).

60 Jałochowski (2020): 14.

61 Karoński (2015): 27.

62 Scheler (1997): 77. 
bardziej ogólnie (tym negatywnie rozumianym) wymiarem emocjonalnym ${ }^{63}$. Jakże inaczej wytłumaczyć nie tylko poczynania ministrów odpowiedzialnych za naukę, ale również brak adekwatnej reakcji ze strony samych - zantagonizowanych zreszta - zainteresowanych ${ }^{64}$. Sytuacja ta doprowadziła do stanu, w którym nie istnieje rzeczowa dyskusja nad celem polityki naukowej państwa, modelem poprawy praktyk wydawniczych, zwiększeniem udziału krajowych zespołów badawczych w międzynarodowych badaniach czy nad konfliktem pokoleniowym w ramach akademii ${ }^{65}$. W rezultacie otrzymujemy chaos (brak nawet krótkookresowego planowania), upolitycznienie (stajace się faktycznym „okrętem flagowym” polskiej nauki, bez pracowników akademickich na pokładzie) i utowarowienie (zwalniajace z dociekań poznawczych na rzecz pogoni za punktami, gwarantującymi bezpieczeństwo ontologiczne zainteresowanym). Dodatkowo beneficjenci łamania prawa i dobrych obyczajów przyklaskują (z pojedynczymi głosami krytyki i zażenowania) kierunkowi postępujących przeobrażeń nauki polskiej, naiwnie wierząc, że „Białostockie Studia Prawnicze” za 100 pkt dogoniły „Harvard Journal of Law \& Public Policy”, „Nieruchomości@: Kwartalnik Ministerstwa Sprawiedliwości” (działający od 2019 r.!) wyprzedził - wydawany przez Taylor \& Francis - „Journal of Real Estate Literature”, o światowej sławy „Archiwach, Bibliotekach i Muzeach Kościelnych” (100 pkt) nie wspominając.

Ajdukiewicz, K. (1965). Język i poznanie. Tom 2. Warszawa: Państwowe Wydawnictwo Naukowe. Akademickość polskich miast (2019). Raport. J. Nowak, M. Wieteska (red.). Warszawa: Polski Instytut Ekonomiczny. <http://pie.net.pl/wp-content/uploads/2019/06/PIE-Raport_Akademicko\%C5\%9B\%C4\%87.pdf>

Arboledas-Lérida, L. (2020). Capital and the scientific endeavour: an appraisal of some Marxist contributions to the debate on the commodification of science. Critique 48(4): 321-367. doi:10.1080/03017605.2020.1850631

Baranowski, M. (2017). Education in times of uncertainty. Uncertainty in education. A critical approach, [w:] A. Odrowąż-Coates, S. Goswami (eds.), Symbolic Violence in Socio-Educational Contexts: A Post-Colonial Critique. Warszawa: Wydawnictwo Akademii Pedagogiki Specjalnej: $63-72$.

Baranowski, M. (2019a). Sociology of knowledge in times determined by knowledge. Society Register 3(1): 7-22. doi:10.14746/sr.2019.3.1.01

Baranowski, M. (2019b). O potrzebie krytycznej teorii społeczeństwa. Przegląd Krytyczny 1(1): 8-16. doi:10.14746/pk.2019.1.1.01

Baranowski, M. (2020). A contribution to the critique of worthless education: between critical pedagogy and welfare sociology. Globalisation, Societies and Education 18(4): 391-405. doi:10.1080/14767724.2020.1732195

${ }^{63}$ Por. Mouffe (2020).

${ }^{64}$ „Jednym ze skutków przemocy symbolicznej jest przekształcenie relacji dominacji i podporządkowania w relacje emocjonalne, zamiana władzy w charyzmę lub wdzięk zdolne wywołać emocjonalne oczarowanie" (Bourdieu 2009: 141).

${ }^{65}$ Jak zauważył Norber Elias (2010: 21): „Nigdy [...] zrozumienie nowych sposobów mówienia i myślenia nie następuje bez konfliktów ze starszymi i lepiej znanymi - wymaga reorganizacji postrzegania i myślenia licznych powiązanych ze sobą osób w danym społeczeństwie. Taka nowa nauka wraz ze zmianą myślenia wielu ludzi i ich przywyknięciem do całego zespołu nowych pojęć lub dawnych pojęć w nowym sensie wymaga dwóch lub trzech pokoleń, a często dużo dłuższego okresu. Może jednak jaśniejsze ujrzenie wspólnego zadania przyspieszy taką reorientację". 
Bourdieu, P. (2009). Rozum praktyczny. O teorii działania. Tłum. J. Stryjczyk. Kraków: Wydawnictwo Uniwersytetu Jagiellońskiego.

Bourdieu, P., Wacquant, L.J.D. (2001). Zaproszenie do socjologii refleksyjnej. Tłum. A. Sawicz. Warszawa: Oficyna Naukowa.

Brzeziński, J. (2000). Poznanie naukowe - poznanie psychologiczne, [w:] J. Strelau (red.), Psychologia. Podręcznik akademicki. Tom 1. Gdańsk: Gdańskie Wydawnictwo Psychologiczne: 333-354.

Chalmers, A. (1997). Czym jest to, co zwiemy nauką? Tłum. A. Chmielewski. Wrocław: Wydawnictwo Siedmioróg.

Chawla, D.S. (2021). Hundreds of 'predatory' journals indexed on leading scholarly database. Nature, February 8. doi:10.1038/d41586-021-00239-0

Czapliński, P. (2019). Uniwersytet antyludowy. Kultura i Rozwój 7: 1-9. doi:10.7366/KIR.2019.7.07

Elias, N. (2010). Czym jest socjologia? Warszawa: Wydawnictwo Aletheia.

Espeland, W.N., Sauder, M. (2016). Engines of Anxiety: Academic Rankings, Reputation, and Accountability. New York: Russell Sage Foundation.

Fromm, E. (2017). Rewolucja nadziei. W stronę uczłowieczonej technologii. Kraków: Wydawnictwo vis-à-vis/Etiuda.

Gadd, E. (2020). University rankings need a rethink. Nature 587: 523. doi:10.1038/d41586-02003312-2

Graeber, D. (2016). Utopia regulaminów. O technologii, tępocie i ukrytych rozkoszach biurokracji. Tłum. M. Jedliński. Warszawa: Wydawnictwo Krytyki Politycznej.

Grudniewicz, A., Moher, D., Cobey, K.D. et al. (2019). Predatory journals: no definitione, no defence. Nature 576: 210-212. doi:10.1038/d41586-019-03759-y

Hobsbawm, E. (2013). Jak zmienić świat? Marks i marksizm 1840-2011. Tłum. S. Szymański. Warszawa: Wydawnictwo Krytyki Politycznej.

Illouz, W. (2010). Uczucia w dobie kapitalizmu. Tłum. Z. Simbierowicz. Warszawa: Oficyna Naukowa.

Jałochowski, M. (2020). Uczelnie - plantacja cherlawych paprotek. Gazeta Wyborcza, 5 lutego 2020: 14 .

Karas, E. (2019). Fake news and the ritualization of the self. Society Register 3(2): 109-121. doi:10.14746/sr.2019.3.2.07

Karoński, M. (2015). Polska nauka czy nauka w Polsce? Nauka 3: 25-33.

Klauziński, S. (2016). Reforma Gowina straszy małe uczelnie. Duże śpią spokojnie. Gazeta Wyborcza, 9 listopada 2016. <https://wyborcza.pl/7,75398,20954043,reforma-gowina-straszy-male-uczelnie-duze-spia-spokojnie.html>.

Klebaniuk, J. (2012). Profesor Stapel na dopingu. O upiększaniu psychologii społecznej. Psychologia Społeczna 7(22): 213-217.

Klementewicz, T. (2019). Niewolnicy Elseviera. Konsensus Waszyngtoński w naukach społecznych? Studia Krytyczne 8: 13-41.

Klementewicz, T. (2020a). Elsevier's slaves: the Washington Consensus in the social sciences? Society Register 4(4): 183-208. doi:10.14746/sr.2020.4.4.09

Klementewicz, T. (2020b). Humanistyka po deformie Gowina. Przegląd 30.11-6.12.2020.

Kmita, J. (1975). Wykłady z logiki i metodologii nauk. Warszawa: Państwowe Wydawnictwo Naukowe.

Kozyr-Kowalski, S. (2005). Uniwersytet a rynek. Poznań: Wydawnictwo Naukowe UAM.

Krzemiński, I. (2019). Destrukcja nauki i uniwersytetu. Rzeczpospolita, 25 marca 2019. <https:// www.rp.pl/Publicystyka/303259918-Destrukcja--nauki-i-uniwersytetu.html>.

Kulikowski, K., Antipow, E. (2020). Niezamierzone konsekwencje punktozy jako wartości kulturowej polskiej społeczności akademickiej. Studia Socjologiczne 3(238): 207-236. doi:10.24425/ sts.2020.132476

Leszczyński, A. (2019). Lista czasopism naukowych: polityczne wpisy, kurioza, pomyłki i błędy. OKO.press, 7 sierpnia 2019. <https://oko.press/lista-czasopism-naukowych-polityczne-wpisy-kurioza-pomylki-i-bledy/?fbclid=IwAR0htIFIfQ18kGxuW0VJ4JY-HRykoriq_2Dw9q2Ag6H24iYmJbZG8q2KWAM>.

Leszczyński, A. (2020). Bodnar broni naukowców przed Gowinem: „Będą oceniani według zasad, których nie znali”. OKO.press, 19 lutego 2020. <https://oko.press/bodnar-broni-naukowcow- 
-przed-gowinem/?utm_medium=Social\&utm_source=Facebook\&fbclid=IwAR32cwlnZEPOB6HXf-qjbl2mptok37ivy2X0rAu0gIGls9-IW9vd-xeulI0\#Echobox=1582131308> .

Leszczyński, A. (2021a). Bałagan w ocenianiu naukowców. Ministerstwo samo nie wie, jak chce punktować publikacje naukowe. OKO.press, 19 stycznia 2021. <https://oko.press/balagan-w-ocenianiu-naukowcow-ministerstwo-samo-nie-wie-jak-chce-punktowac-publikacje-naukowe/s.

Leszczyński, A. (2021b). Prof. Kulczycki: Czarnek będzie ręcznie sterował nauką i rozdzielał pieniądze według uznania. OKO.press, 23 lutego 2021. <https://oko.press/prof-kulczycki-czarnek-bedzie-recznie-sterowal-nauka/?utm_medium=Social\&utm_source=Facebook\&fbclid=IwAR3dJJdAMXip9UfPqN_LWkA58KQ5wPdoab832SDjpIOhhOl4xMMyRJ2ryBE\#Echobox $=1614062870>$.

Lim, S. (2020). Academic library guides for trackling fake news: a content analysis. The Journal of Academic Librarianship 46(5). doi:10.1016/j.acalib.2020.102195

Lydgate, Ch. (2018). Reed and the rankings game. Reed College, September 12, 2018. <https:// www.reed.edu/apply/college-rankings.html>.

McKenna, S. (2020). University rankings don't measure what matters. The Conversation, September 14, 2020. <https://theconversation.com/university-rankings-dont-measure-what-matters-145425>.

Ministerstwo Edukacji i Nauki (2021). Nowy, rozszerzony wykaz czasopism naukowych i recenzowanych materiałów z konferencji międzynarodowych. <https://www.gov.pl/web/ edukacja-i-nauka/nowy-rozszerzony-wykaz-czasopism-naukowych-i-recenzowanych-materialow-z-konferencji-miedzynarodowych?fbclid=IwAR0X2uuxqNtkNYSfskTti4zcj0mkvbsqQMQGP92OUcqs-d7xxjxM7DbAy5g>.

Molina, M.D., Sundar, S.S., Le, T., Lee, D. (2021). "Fake news" is not simply false information: a concept explication and taxonomy of online content. American Behavioral Scientist 65(2): 180-212. doi:10.1177/0002764219878224

Mouffe, Ch. (2020). W obronie lewicowego populizmu. Tłum. B. Szelewa. Warszawa: Wydawnictwo Krytyki Politycznej.

Nature (2019). Experts must demand to be heard. Nature 572: 153.

Nowak, A.W. (2010). Uniwersytet to akcelerator podziałów klasowych. Z Andrzejem W. Nowakiem rozmawia Krystian Szadkowski. Praktyka Teoretyczna 1: 209-216.

Nowakowska, K. (2018). Likwidacja humanistyki w białych rękawiczkach. Ministerstwo drastycznie zmniejsza finansowanie. Dziennik Gazeta Prawna, 11 grudnia 2018. <https:// serwisy.gazetaprawna.pl/edukacja/artykuly/1386551,jak-gowin-likwiduje-humanistyke-na-polskich-uczelniach.html?fbclid=IwAR0J5bEXcLTMg4v5YIOExBH2k2q1H8tRRXEk_ NTdBDxKqpvhumeDtCKuulA>.

Odrowąz-Coates, A. (2020). Chaos theory and the neoliberal English-based dimension of the Polish higher education reforms 2018/2019. Education as Change 24: 1-19. doi:10.25159/1947$9417 / 5913$

Pedrini, P.P. (2019). Fake news as a weapon of persuasion. Society Register 3(2): 97-108. doi:10.14746/sr.2019.3.2.06

Pezda, A., Uhlig, D. (2008). Reforma Kudryckiej, czyli doktor bez magisterki. Gazeta Wyborcza, 17 kwietnia 2008. <https://wyborcza.pl/1,75398,5127043.html>.

Pokusińska, A. (2020). Analiza procesu utowarowienia edukacji z wyszczególnieniem szkolnictwa wyższego. Przegląd Krytyczny 2(1): 91-108. doi:10.14746/pk.2020.2.1.06

Russell, B. (1995). Władza i jednostka. Tłum. H. Jankowska. Warszawa: Książka i Wiedza.

Russell, B. (1997). Szkice niepopularne. Tłum. H. Jankowska. Warszawa: Książka i Wiedza.

Scheler, M. (1997). Resentyment a moralność. Tłum. J. Garewicz. Warszawa: Czytelnik.

Schumpeter, J.A. (1984). The meaning of rationality in the social sciences. Zeitschrift für die gesamte Staatswissenschaft / Journal of Institutional and Theoretical Economics 140(4): 577-593.

Sewastianowicz, M. (2021). Wrzutka na liście punktowanych czasopism - niektóre nagle docenione. Prawo.pl, 12 lutego 2021. <https://www.prawo.pl/student/lista-czasopism-punktowanych-2021-nieprawidlowosci-procedura,506410.html?fbclid=IwAR2uho6fTknZb8ISm_Su476y-hfJ4knawM1OKHa0TGkGCu-Y6RnOpmC5SLI>.

Sloterdijk, P. (2011). Kryształowy pałac. O filozoficzną teorię globalizacji. Tłum. B. Cymbrowski. Warszawa: Wydawnictwo Krytyki Politycznej. 
Słomczyński, T. (2021). Pytania za 100 punktów. WP Magazyn, 21 lutego 2021. <https://magazyn. wp.pl/ksiazki/artykul/pytania-za-100-punktow>.

Sobczak, K. (2021). Prof. Wierczyński: Zmiany na liście czasopism bezprawne, kiedyś do cofnięcia. Prawo.pl, 18 lutego 2021. <https://www.prawo.pl/student/zmiany-na-liscie-czasopism-naukowych-wg-prof-grzegorza, 506538.html>.

Such, J., Szcześniak, M. (1997). Filozofia nauki. Poznań: Wydawnictwo Naukowe UAM.

Sullivan, M.C. (2019). Libraries and fake news: what's the problem? What's the plan? Communications in Information Literacy 13(1): 91-113. doi:10.15760/comminfolit.2019.13.1.7

Szczepański, J. (2021). Trzeba zreformować system ewaluacji w nauce. Dziennik Gazeta Prawna, 17 lutego 2021. <https://serwisy.gazetaprawna.pl/edukacja/artykuly/8097696,dr-jaroslaw-szczepanski-czarnek-czasopisma-punktowane-opinia.html>.

Śliwerski, B. (2019). Stanowisko Komitetu Kryzysowego Humanistyki Polskiej w sprawie (dysfunkcji i patologii) nauki i szkolnictwa wyższego z postulatami zmian. Pedagog, 1 października 2019. <https://sliwerski-pedagog.blogspot.com/2019/10/stanowisko-komitetu-kryzysowego.html>.

Tittenbrun, J. (2014). Kolonizacja nauki i świata przez kapitał. Teoria światów równoległych w wydaniu socjologii wiedzy. Poznań: Zysk i S-ka Wydawnictwo.

Tomala, L. (2019). Gowin: w uniki naszych uczelni w rankingach poprawią się w ciagu kilku lat. Nauka w Polsce, 3 października 2019. <https://naukawpolsce.pap.pl/aktualnosci/news\%2C78843\%2Cgowin-wyniki-naszych-uczelni-w-rankingach-poprawia-sie-w-ciagu-kilku-lat>.

Touraine, A. (2010). O socjologii. Tłum. M. Warchala. Warszawa: Wydawnictwo Naukowe PWN.

Veblen, T. (2008). Teoria klasy próżniaczej. Tłum. J. Frentzel-Zagórska. Warszawa: Muza.

Walicki, A. (2013). Nieświęty sojusz biurokracji z rynkiem. Gazeta Wyborcza, 31 maja 2013. <https:// wyborcza.pl/magazyn/1,124059,14014327,Nieswiety_sojusz_biurokracji_z_rynkiem.html>.

Welsh, J. (2020). Tolling academics: rent-seeking and gatekeeping in the university space. Capital \& Class 1-29. doi:10.1177/0309816819900131

Whitehead, A.N. (1929). The Aims of Education and other Essays. New York: Macmillan.

Ziętek-Kwaśniewska, K. (2020). Nakłady na działalność badawczo-rozwojową w Polsce na tle państw Unii Europejskiej. Studia BAS 1(61): 9-25.

Ziółkowski, M., Drozdowski, R., Baranowski, M. (2020). Utowarowienie i odtowarowienie w ujęciu socjologicznym: próba (re)konceptualizacji. Studia Socjologiczne 3(238): 53-77. doi: 10.24425/ sts. 2020.132470

\section{RESENTMENT RATIONALISM IN THE EVALUATION OF POLISH SCIENTIFIC JOURNALS: CHAOS, POLITICIZATION AND COMMODIFICATION}

\section{Summary}

The article aims to characterise the evaluation of Polish scientific journals in the fields of the humanities and social sciences, in the broader context of national science and higher education reforms. For this purpose, the notion of resentment rationalism, referring to Max Scheler's work, was introduced to highlight the disorganization of successive attempts to rebuild the system of science rooted in evil and atavistic passions. As a consequence of the adopted research optics, what emerges is a picture of chaotic, politicized and commodified reforms, which fail to correct the position of Polish science and antagonize the community of researchers, by making it impossible to deal with important structural problems in this field.

Keywords: Polish science; 'pointosis'; journals' evaluation; commodification; resentment rationalism 
